\title{
歴史的町並みの魅力と観光者類型に関する定量分析
}

\author{
赤沢 克洋 (島根大学) \\ 福谷 紗矢（島根大学生物資源科学部）

\section{Quantitative Analysis of Attractiveness and Tourist Segmentation on Historical Townscape Areas}

\author{
Katsuhiro Akazawa (Shimane University) \\ Saya Fukutani (Faculty of Life and Environmental Science, Shimane University)
}

It is essential to consider the various segments, or demographic groups, of tourists during marketing process planning and management of a historical townscape area. In addition, it is important to understand the motives for touring this type of area as one of the criteria of segmentation, since this segmentation enables town administrators to clarify the needs of tourists visiting their area. The purpose of this study is to typify tourists who visit the historical townscape areas of Kurashiki or Takayama. For this

\section{1. 研究の背景と目的}

我が国にお咑る大規模な国土開発及び都市化と対 峙あるいは共存して, 歴史的町並又を保存・活用す る取り組みが半世紀以上にもわたってなされて招り (大山, 2009), 現在でもいくつかの地方自治体にとっ て歴史的町並夕の資源管理が政策課題の1つとなっ ている.このとき歴史的町並夕の資源管理に打ける 重要な戦略方途の 1 つとして注目されるのは観光活 用であり，このためにはマーケティング管理が必要 となる。

顧客のニーズに応じた製品戦略はマーケティング 管理の基本であり，それは歴史的町並又に扔いても 例外ではない，つまり，観光活用を図る個々の歴史 的町並みの管理主体にとって, 当該観光地の魅力に 対する観光者の希求点及びその結果としての訪問理 由を定量的に把握することがマーケティング管理の 第 1 歩となる.

歷史的町並又は, 複数の歴史的・伝統的な建造物 を核としながら自然やその他の人工物が配置された 空間であるため, 広がりを持つ空間全体が財・サー purpose, we apply the latent class analysis to the data about the motives for touring these two areas. Consequently, several classes of tourists are identified, divided by the importance of attractiveness from the aspect of motives for a tour. It can then be cleared which segments of tourists place a high value on the historical townscape area's general attractiveness, a specific attractiveness, or no attractiveness.

ビスの根本となり，また空間内に民間資本を含めた 多種の観光資源・施設が存在する複合観光資源とな る.つまり, 歴史的町並久は多様な魅力を内包寸る. このため, 歴史的町並又は, 観光者間で希求する魅 力,いいかえれば魅力に依拠した訪問理由が異なり， 1 つの財・サービスではあるが，魅力に依拠した訪 問理由を分割基準とした観光者層が形成されている 可能性が高い. したがって，マーケティング管理に 打ける基礎的知見である観光者の希求点及び訪問理 由を把握するにはこのような観光者層の定量的抽出 による接近が適している.

既存研究を概観すると，観光地の魅力を計測する 包括的かつ定量的な枠組みを提示した室谷（1998） の貢献は大きく, 後述のよらに歴史的町並夕の魅力 に関する研究（尾家，2005; カロリン，2005; 濱田， 2011 等）も存在する。しかし，歴史的町並夕に掠 ける観光者層の定量的抽出に関する取り組みは管見 の限り十分ではない.

以上から本研究では, 歴史的町並みの魅力を要素 とする訪問理由を基準として観光者を類型化するこ 
とを通して，歴史的町並みの魅力に対する観光者の 希求点を明らかにすることを目的とする。 このため の分析方法を若干説明すると, 類型化の基準となる 魅力に依拠した訪問理由については観光心理学の知 見を援用して整理する. また, 訪問理由に関するデー タについては特定の歴史的町並みを訪孔た観光者を 対象としたアンケート調査を実施して収集する。さ らに，得られたデータを用いた観光者の類型化には 潜在クラス分析 ${ }^{1)}$ 適用する.

\section{2. 歴史的町並みへの訪問理由}

\section{（1）観光心理学における訪問理由の意味づけ}

観光心理学 ${ }^{2)}$ では, 様々な行動の中で旅行行動を 選択する働きをする心理的要因は発動要因とよば れ, 様々な観光地の中で特定の観光地を選択させる 働きをする心理的要因は誘引要因とよばれる，発動 要因は観光者の快欲求とそれを満たすための脱日常 性欲求及び新奇性欲求が源となり, 誘引要因は観光 地の価值や魅力を構成要素としている.

これらの発動要因と誘引要因との相互作用により 動機付けが行われ, 動機付けの内容や強さにより特 定の観光地への旅行行動が生じるとされる(佐々木, 2007). したがって, 特定観光地への観光者の訪問 理由は，大枠としては発動要因と誘引要因にあり， 観光者の脱日常性欲求及び新奇性欲求に基づく要因 々観光地の魅力に基づく要因であるといえる.

発動要因は旅行行動により満たされ，その満足さ せるものの 1 つが誘引要因すなわち観光地の魅力で ある.つまり, もし観光者が観光地を訪孔たならば, 観光地の魅力が何らかの発動要因を満足させる機会 を提供していると考兄られる. したがって, 観光地 の視点に立てば, いくつかの発動要因は観光者心理 の局面で捉えた観光地の魅力であり, 観光者心理に 及ぼす観光地の副次的な魅力であるといえる.

そこで本研究では, 観光地がマーケティング管理 を直接的に行うことができる領域を念頭に扣き，発 動要因の中で観光地との関わりが薄い旅行行動に よって満たされるものとこれに依拠した訪問理由に ついては若干の検討を加えるに留め, 観光地の魅力 と観光者心理に及ぼす観光地の副次的な魅力を訪問 理由として捉える.

\section{（2）歴史的町並みの魅力による訪問理由の整理}

前述の検討をべースとして, 歴史的町並みへの訪
問理由を整理すると, 第 1 に, 歴史的町並又の本源 的資源の魅力である。前述のように，歴史的町並又 は城下町, 宿場町, 門前町などのように複数の歴史 的・伝統的な建造物を核としながら自然やその他の 人工物が配置された空間であるとされる。したがっ て，歴史的な趣のある空間と個々の建造物が歴史的 町並みの本源的な資源である。このような観光地を 特徵付ける本源的資源に着目することは観光地の価 值や魅力を検討する際に必然であり，関連する既存 研究は枚挙に暇がない.

第 2 亿, 観光地としての価值を高めるために本源 的資源に付加して提供されるサービス資源の魅力で ある、既存研究から訪問理由や評価対象となるサ一 ビス資源をみると，食事施設，物販施設などの有形 な資源，イベント開催やホスピタリティなどの無形 な資源が挙げられる ${ }^{3)}$.

第 3 に, 観光者心理に及活す歴史的町並久の副次 的な魅力である。例えば，歴史的町並みは，歴史的 な趣のある空間と個々の建造物, 資料館や博物館な どによって歴史・文化を学びたいといら発動要因に 応える機会を提供して和り，歴史・文化を学べると いら副次的な魅力を持つといえる. 同様に，歴史的 町並みは空間的な広がりを持つため, 発動要因に応 える場所・機会の提供を通して，同行者と行動を共 にできる，散策できる，写真が撮影できる等の副次 的な魅力を持つと考兄られる。実際に歴史的町並久 に関する既存研究をみると, 日常生活と離孔た非日 常性（濱田, 2011）あるいは旅行地の生活感（尾家, 2005）を感じられること，日常の緊張から解放され てリラックスできること,歩くことができること(尾 家，2005；カロリン，2005）, 同行者との時間を過 ごせること（カロリン，2005）等が訪問理由として 挙げられている.

\section{3. データ}

歴史的町並みへの訪問理由に関するデータの収集 を目的としてアンケート調査を実施した。

調査対象地は岡山県倉敷市の倉敷美観地区（以下， 倉敷）と岐阜県高山市の高山の古い町並又（以下， 高山）である. 両対象地ともに重要伝統的建造物群 保存地区に選定されて和り，また 2011 年までの 10 年間の平均で倉敷美観地区が 318 万人，旧高山市が 294 万人の観光者を集めて扔り ${ }^{4)}$ ，観光対象としての 
歴史的町並みの性質を十分に有しているといえる.

アンケート調査の主たる質問項目は訪問理由に関 寸るものであり, 表 1 亿示寸魅力項目が当該観光地 を訪問した理由として「重要であるか，否か」を尋 ねた 2 值データとなる。

調查日は倉敷が 2012 年 11 月 21 日，23〜 25 日， 高山が 10 月 $18 \sim 22$ 日， $24 \sim 27$ 日， 11 月 $10 \sim 14$ 日であった。 その結果，345人（うち倉敷 186 人， 高山 159 人）から回答が得られた.

\section{4. 観光者類型の抽出}

\section{（1）訪問理由の集計結果}

観光者類型の抽出の前飞訪問理由としての魅力項 目の選択率（表 1）を簡単にみて特こう。魅力項目 全体での平均は 0.375 (倉敷), 0.306 (高山）であり, 選択率はそれ汪ど高くない. 高山よりも倉敷の方が 全般的に高い選択率をとる傾向にあった。

各魅力項目をみると, 町並み, 雾囲気といった本 源的資源の魅力が高い選択率をとるが訪問理由とし て決定的とまではいえず，買い物，食事，リラック ス，非日常性と同行者関連，写真などのサービス資 源の魅力及び観光者心理に関わる副次的魅力につい ても訪問理由となっていることがわかる. 他方, サー ビス資源と副次的魅力では選択率が 0.200 以下の魅 力項目も多くみられた.

\section{(2) 抽出の手順}

データには各観光者が各魅力項目を訪問理由とし て重視するか，否かを回答した結果を用い，抽出方 法には潜在クラス分析を採用した。つまり, 各観光 者の訪問理由に関する回答の背後には各魅力を訪問 理由として重視する潜在的な傾向が存在することを 想定し, 同質の潜在的傾向を持つ観光者群により観 光者類型が確率的に構成されるとした，

潜在クラス分析により抽出される観光者類型は当 該類型の観光者が各魅力を重視する条件付き応答確 率（以下，応答確率）により表現される。この応答 確率の高低に基づいて各類型の潜在的傾向の特徴を 解釈することが可能である. 本研究では, 応答確率 が選択率以上となる魅力項目と選択率の拈拈よその 最大值である 0.700 以上となる魅力項目とに注目す ることによって各観光者類型に打注訪問理由の潜 在的傾向を特徵付けた.

潜在クラス分析では, クラス数 (類型数) に応じ
たモデルを複数抽出し，いくつかの指標等を判断基 準としながら 1 つのモデルに絞り込んでいく，しか し，マーケティング管理の各プロセスは下流のプロ セスからのフィードバックによる修正がなされるな ぞ相互に関連している。つまり，七グメンテーショ ンについても他のプロセスと独立に決定されるわけ ではない，そこで本研究では各観光者類型を特徴付 けることができたモデルを併記することとする．

\section{（3）倉敷ケースにおける観光者類型}

潜在クラス分析を実行したところ類型数 2 から 5 までのモデルにおいて観光者類型を特徵付けること ができた．表 1 には，紙幅の都合上 3 類型モデルと 4 類型モデルの結果のみを示している.

各モデルに抢ける観光者類型の潜在的傾向を順に 解釈していくと，2 類型モデルでは，すべての魅力 項目に打いて類型 2-2（所属確率：0.281）が類型 2-1 を大きく上回って括り，潜在的傾向には類型間 で明確な差が見られた。

3 類型モデルをみると, 類型 3-1 と類型 3-2 は主 に類型 2-1 が分割したものである．類型 3-1 は，建 造物，美術館，歴史文化といった歴史や文化に関わ るポイント型の魅力が訪問理由となっているが顕著 ではなく，大枠では希薄な訪問理由が基調であるの で理由希薄傾向といえよう。

類型 3-2 では，ポイント型の魅力の応答確率が極 めて低い一方，町並久，雰囲気，リラックス，同行 者関連が訪問理由となる確率が高く, 非日常関連, 写真等についても応答確率が選択率を上回ってい る。つまり，広がりに関わる本源的資源の魅力とそ れに起因した副次的魅力が訪問理由となって抢り, ノンポイント魅力傾向と特徵付けられる。

類型 3-3 は類型 2-2 亿概衫対応して打り，本源的 資源の魅力，サービス資源の魅力及び副次的魅力の 3つの魅力とも訪問理由として重視する魅力全般傾 向である。

4 類型モデルでは，類型 4-1 は類型 3-1 に概初対 応し，理由希薄傾向といえる．類型 4-2 は類型 3-2 をべースとしながらも全般的に訪問理由がより希薄 である。ただし，応答確率が 0.700 以上の魅力項目 を辿ると歷史的町並又の䨌囲気の中で同行者之過ご すことができるといら訪問理由が推察できる。そこ で類型 4-2 は同行者重視傾向であるとした.

類型 4-3 と類型 4-4 は魅力項目全般にわたって応 
表 1. 訪問理由としての選択率及び潜在クラス分析による観光者類型の抽出結果

\begin{tabular}{|c|c|c|c|c|c|c|c|c|c|c|c|c|c|c|c|c|}
\hline \multirow{4}{*}{ 魅力項目 } & \multicolumn{8}{|c|}{ 倉敷 } & \multicolumn{8}{|c|}{ 高山 } \\
\hline & \multirow{3}{*}{$\begin{array}{l}\text { 選 } \\
\text { 択 } \\
\text { 率 }\end{array}$} & \multicolumn{7}{|c|}{ 条件付き応答確率 } & \multirow{3}{*}{$\begin{array}{l}\text { 選 } \\
\text { 択 } \\
\text { 率 }\end{array}$} & \multicolumn{7}{|c|}{ 条件付き応答確率 } \\
\hline & & \multicolumn{3}{|c|}{3 類型モデル } & \multicolumn{4}{|c|}{4 類型モデル } & & \multicolumn{3}{|c|}{3 類型モデル } & \multicolumn{4}{|c|}{4 類型モデル } \\
\hline & & $3-1$ & $3-2$ & $3-3$ & $4-1$ & $4-2$ & $4-3$ & $4-4$ & & $3-1$ & $3-2$ & $3-3$ & $4-1$ & $4-2$ & $4-3$ & $4-4$ \\
\hline 町並み & .742 & .579 & .775 & $\underline{1.00}$ & .576 & .702 & $\underline{1.00}$ & $\underline{1.00}$ & .629 & .523 & .873 & .486 & .795 & .668 & .374 & .491 \\
\hline 雾囲気 & .672 & .480 & .732 & .946 & .455 & .722 & .891 & .930 & .642 & .480 & .898 & .748 & .871 & .601 & .245 & .787 \\
\hline 建造物 & .505 & .540 & .216 & .867 & .580 & .163 & $\underline{1.00}$ & $\underline{1.00}$ & .409 & .268 & .532 & .777 & .489 & .299 & .239 & .772 \\
\hline 美術館 & .285 & .307 & .062 & .570 & .323 & .082 & .271 & $\underline{1.00}$ & .107 & .036 & .147 & .354 & .154 & .000 & .000 & .444 \\
\hline 買い物 & .457 & .274 & .509 & .724 & .254 & .493 & .652 & .777 & .503 & .325 & .939 & .196 & .881 & .384 & .186 & .179 \\
\hline 食事 & .344 & .161 & .274 & .790 & .160 & .206 & .642 & $\underline{1.00}$ & .459 & .332 & .700 & .431 & .688 & .340 & .264 & .391 \\
\hline 扣もてなし & .145 & .069 & .066 & .404 & .075 & .045 & .271 & .561 & .176 & .054 & .344 & .329 & .348 & .000 & .075 & .251 \\
\hline イベント & .113 & .035 & .054 & .346 & .031 & .066 & .142 & .661 & .082 & .020 & .164 & .163 & .153 & .019 & .021 & .125 \\
\hline リラックス & .586 & .310 & .752 & .860 & .290 & .689 & .839 & .928 & .440 & .459 & .514 & .142 & .558 & .293 & .601 & .083 \\
\hline 非日常見る & .516 & .279 & .594 & .846 & .290 & .465 & .870 & .848 & .472 & .402 & .597 & .477 & .586 & .696 & .000 & .486 \\
\hline 同行者時間 & .527 & .142 & .813 & .830 & .092 & .766 & .856 & .784 & .365 & .299 & .618 & .000 & .607 & .106 & .434 & .057 \\
\hline 写真 & .532 & .341 & .564 & .844 & .320 & .520 & .858 & .711 & .352 & .253 & .435 & .626 & .445 & .260 & .201 & .588 \\
\hline 歩くこと & .446 & .298 & .453 & .714 & .308 & .382 & .711 & .640 & .333 & .196 & .558 & .405 & .528 & .143 & .244 & .341 \\
\hline 同行者会話 & .441 & .095 & .648 & .786 & .086 & .556 & .755 & .856 & .327 & .199 & .617 & .170 & .607 & .106 & .434 & .057 \\
\hline 非日常経験 & .360 & .149 & .414 & .678 & .156 & .295 & .645 & .849 & .245 & .211 & .364 & .092 & .353 & .371 & .000 & .065 \\
\hline 歴史文化 & .290 & .309 & .000 & .682 & .343 & .000 & .376 & $\underline{1.00}$ & .245 & .145 & .235 & .776 & .201 & .156 & .136 & .854 \\
\hline 予定地巡る & .274 & .151 & .279 & .499 & .147 & .223 & .425 & .706 & .132 & .032 & .225 & .381 & .206 & .000 & .047 & .397 \\
\hline 地域の生活 & .194 & .122 & .082 & .491 & .135 & .041 & .337 & .721 & .182 & .042 & .234 & .748 & .223 & .090 & .000 & .661 \\
\hline にぎわい & .156 & .000 & .148 & .461 & .000 & .073 & .363 & .701 & .164 & .038 & .396 & .151 & .349 & .000 & .071 & .143 \\
\hline 時間つぶし & .172 & .052 & .177 & .390 & .055 & .108 & .356 & .507 & .094 & .081 & .126 & .073 & .131 & .025 & .135 & .062 \\
\hline 地図で巡る & .118 & .091 & .026 & .305 & .099 & .027 & .081 & .723 & .075 & .000 & .180 & .167 & .151 & .000 & .000 & .170 \\
\hline 所属確率 & & .432 & .338 & .230 & .387 & .316 & .224 & .074 & & .572 & .314 & .114 & .377 & .284 & .230 & .110 \\
\hline
\end{tabular}

表注 1）下線及び斜字体はとれぞれ条件付き応答確率が選択率以上，0.700 以上となることを示す。

答確率が平均を超えて打り，魅力全般傾向にある. また，本源的資源の魅力と選択率の高い副次的魅力 （リラックス，非日常関連，同行者関連，写真）に おいて応答確率が高いことが両類型に共通する特徵 である。他方，サービス資源の魅力と選択率の低い 魅力項目の多くに括いて類型 4-3 の応答確率が相対 的に低く，両者には差がみられた。 また，類型 4-4 は魅力全般傾向と解釈した類型 3-3 と比べても各魅 力項目の応答確率が高い. そこで類型 4-3 を本源的・ 一般副次的魅力傾向, 類型 4-4 を魅力全般満喫傾向 と解釈した.

5 類型モデルは類型 4-1 が 2 つの類型（類型 5-1, 類型 5-5）に分割されたものである. 類型 5-1（応答 確率:0.719) は理由希薄傾向であり,類型 5-5 (0.074) は建造物, 打もてなし, 同行者会話, 歴史文化, 歩 くこと, 地図, 地域の生活の応答確率が高いことか
ら建造物巡り重視傾向であると解釈した。

\section{（4）高山ケースにおける観光者類型}

高山ケースでは, 類型数 2 から 4 までのモデルに おいて観光者類型を特徵付けることができた．表 1 に，3 類型モデルと 4 類型モデルの結果を示す。

2 類型モデルでは, 類型 2-2（所属確率：0.474) の応答確率が相対的に高い傾向にあった.

3 類型モデルでは, 類型 3-1 は理由希薄傾向であ ると判断できる. 類型 3-2 は，すべての魅力項目の 応答確率が選択率を超えて和り，特に，町並及，䨌 团気，食事，買い物が高いことから，町並みサービ 又重視傾向と解釈した．類型 3-3 は，建造物，雾囲 気, 写真, 歴史文化, 地域の生活の応答確率が高く, 文化重視傾向と解釈できる.

4 類型モデルでは, 類型 4-1 と類型 4-4 がそれぞ 孔類型 3-2 と類型 3-3 飞対応して扣り，町並みサ一 
ビス重視傾向，文化重視傾向である．類型 4-2 と類 型 4-3 は, 類型 3-1 が分割されたものであり, 理由 希薄傾向を基調としている. このらち類型 4-2 は町 並夕, 非日常見るの応答確率が 0.7 程度であり, 理 由希薄・非日常傾向とした. 類型 4-3 はリラックス, 同行者時間の応答確率が高いことにより類型 4-2 と 差別化されるが訪問理由として顕著に重視されてい るとはいえないので理由希薄傾向と解釈した.

\section{5. 検討}

ここでは, 抽出された観光者類型から歴史的町並 夕の魅力に関寸る観光者の希求点を整理していく.

倉敷ケースの類型 3-2, 類型 4-2 及び類型 5-2 では, 同行者との時間やリラックスする時間を過ごせるこ と及びそれを可能にする場所や機会として町並みや その雾囲気の中で写真を撮ったり，買い物したり， 散策したりできることが訪問理由として重視されて 打り, これらに属寸る観光者層が希求する魅力は空 間的・時間的な広がりである，広がりのある空間で あり，複合観光資源であるといら財特性を持つ歴史 的町並久特有の希求点であるといえよう。

高山ケースの類型 3-2, 類型 4-1 に属する観光者 層の希求点は, 町並夕, 雾囲気, 買い物, 食事といっ た歴史的町並又の第 1 ，第 2 の魅力が提供されるこ とであり，それらの副次的な魅力も文字通りプラス 要因となっている．前述の倉敷ケースと比べると希 求される魅力項目は同様であるが，第 1 , 第 2 の魅 力の比重が大きいのが高山ケースの特徴である。 こ れは空間構成が面的な倉敷に対して高山では線的で あることが影響していると考兄られる。

倉敷ケースの類型 5-5 あるいは高山ケースの類型 3-3 と類型 4-4 は限定的な魅力を求める観光者層で

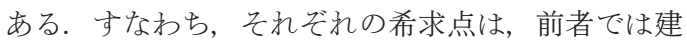
造物を巡ることを主軸として関連する副次的魅力も 享受できること, 後者では歴史的町並又の第 1 , 第 3 の魅力の区別なく地域の歴史や文化を学ぶことに 関連した魅力を提供されることである.

歴史的町並又の魅力全般を訪問理由として重視す る観光者層が一定数存在する. これ䛉該当するのは 倉敷ケースの類型 3-3, 類型 4-3, 類型 4-4, 類型 5-3 及び類型 5-4 である。 これらの観光者層は，歴 史的町並又に求める魅力が全般にわたるだけでな く, 歴史的町並夕に対して高い関与と知識を持ち,
魅力に対する要求水準が高いことが推察される。し たがって，これらの観光者層には十分差別化された 魅力を訴求していくことが必要となる。一方，歴史 的町並みの魅力への受容性が高いため, リピーター, ファン，パートナー，鼓吹者といった観光地との強 固な関係の構築が見込める観光者層だともいえるだ 万う。

倉敷ケースの類型 3-1，類型 4-1 及び類型 5-1，高 山ケースの類型 3-1 とそれが分割された類型 4-2 と 類型 4-3 から明らかなよらに，倉敷と高山の両ケ一 スのいずれのモデルに拈いても訪問理由が希薄な観 光者層が存在する。

これらの観光者層では，例えば，「他の観光地訪問 やパックッアーへの参加が旅行動機であり，消極的 理由により訪れた」といった歴史的町並みの魅力と は関連が薄い旅行行動全体によって満たされる発動 要因が訪問理由となっている可能性が高い，本研究 では，希求する魅力に応じた製品戦略の基礎的材料 の提示を企図しているため，歴史的町並夕の魅力と は関連が薄い発動要因を敢光て分析範囲外とした が，このよらな発動要因に基づく観光者層の構成割 合が高いことは今後に課題が残されたことを示して いる.

ただし，観光地が直接的に関与できる領域に明確 な希求点を持たない観光者層が存在するといら本研 究で得られた情報は，戦略の 2 つの方向性に関する 示唆を与える。すなわち，第 1 亿，歴史的町並又の 魅力に訴求点がない，もしくは訴求点が事前情報と して十分提供されていなくても一定数の訪問が見込 まれる，比較的対処しやすい観光者であるため，魅 力に応じた製品戦略に関しては浅いマーケティング 管理で短期的には十分であるという戦略の方向性で ある。

第 2 に，歴史的町並みの魅力に対する明確な希求 点がないことは観光者と観光地との関係が希薄であ ることを意味して扣り，このため他の観光地や代替 レジャーの存在により観光者層が不安定になること, 当該観光地あるいは観光行動に対する関与と知識の 水準が低いために要求水準は低いものの魅力の受容 性が低いことが推察されることから，魅力に応じた 製品戦略を展開寸るには深いマーケティング管理が 長期的には必要であるという戦略の方向性である。

歴史的町並夕の魅力に希求点がない観光者層に対 
するマーケティング管理の長短深浅の決定は, 歴史 的町並みのマーケティング環境に依存するため，こ こでは容易に判断を下すことはできないが，観光地 域全体の戦略が 1 つの判断材料となる。 また，前述 の歷史的町並久の魅力と関連の薄い発動要因もその 重要な鍵となるだろう。この点からもこれらの発動 要因に対する検討が至急の課題となるといえる.

\section{6. 結論と今後の課題}

本研究では，ケーススタディではあるが，歴史的 町並みを訪孔る観光者が希求する魅力を観光者層の 視点から検討した. その結果, 空間的・時間的な広 がりから得られる魅力を希求する観光者層, 副次的 魅力も含めた建造物巡りや歴史 - 文化等の特定の魅 力を希求する観光者層, 本源的資源の魅力, サービ 久資源の魅力及び副次的魅力のいずれも希求する観 光者層, 歴史的町並みの魅力に希求点がない観光者 層が見いだせた。

歴史的町並みの魅力に希求点がない観光者層につ いては, 本研究で取り上げなかった歴史的町並みの 魅力との関連が薄い旅行行動全体に関わる発動要因 が鍵となり, 希求する魅力に応じた製品戦略とは異 なったアプローチが必要となる。したがって，この 点に関する調查・分析・検討が今後の課題となる. このとき, 顧客特性, 回遊行動, 支出行動等を解明 することもまた必要な課題とならう.

注 1）潜在クラス分析については藤原他（2012）参照.

2）佐々木（2007）を参考にした。

3）第 1 の魅力と第 2 の魅力に関する既存研究には, 国枝（2010），鎌田他（2006）, 濱田（2011），林他 (2011), 室谷（1998）, 和田（2007）等がある.

4) 岡山県産業労働部観光課 (2011), 高山市商工観光 部観光課（2011）のデータから算出した.

\section{引用文献}

尾家建生（2005）「町並久観光が日本のッーリズム に及ぼす影響について」『日本観光研究学会論
文集』20, pp. 13-16.

大山坬央 (2009)「歴史的町並久保存に関する研究 動向」『史学論叢』39, pp. 50-64.

岡山県産業労働部観光課 (2011) 『観光客・その流 れと傾向一平成 23 年岡山県観光客動態調査報 告書一』.

鎌田裕美・山内弘隆（2006）「観光需要に影響を及 ぼす要因について一「魅力度」計測への試み一」 『国際交通安全学会誌』31, pp. 6-12.

カロリン（2005）「町並み, 眺望と沿岸景観一観光資 源としての斜面地区一」『日本研究特集号』3, pp. 49-62.

国枝よしみ（2010）「奈良県吉野山に打ける観光客 の満足モデルの一考察」『日本観光研究学会論 文集』25, pp. 273-276.

佐々木土師二（2007）『観光旅行の心理学』北大路 書房.

高山市商工観光部観光課（2011）『平成 23 年観光統 計』.

濱田泰（2011）「湯田温泉と萩の魅力の違いと定量 化による比較」『東アジア研究』9, pp. 1-20.

林幸史・岡本卓也・藤原武弘（2011）「旅行者の 目に映る観光地一投影された写真で見る観光地 の魅力」『日本観光研究学会論文集』 $26, \mathrm{pp}$. $45-48$.

藤原 翔・伊藤理史・谷岡 謙（2012）「潜在クラ ス分析を用いた計量社会的アプローチー地位の 非一貫性，格差意識，権威主義的伝統主義を 例に」『年報人間科学』38, pp. 43-68.

室谷正裕（1998）「観光地の魅力評価一魅力ある国 内観光地の整備に向けて一」『運輸政策研究』1, pp. 14-24.

和田早代 (2007)「宿泊業に打けるホスピタリティー に関する研究一北海道の温泉宿泊施設を中心 にして一」『日本観光研究学会論文集』22, pp. 65-68.

（受理日：2014 年 6 月 2 日） 